\title{
КУЛЬТУРОЛОГИЯ
}

UDC 379.85

\section{Russia and China in the field of international tourism}

\author{
A. S. Matveevskaya ${ }^{1}$, S. N. Pogodin ${ }^{2}$, Wang Jun Tao ${ }^{2}$ \\ ${ }^{1}$ St. Petersburg State University, \\ 7-9, Universitetskaya nab., St. Petersburg, 199034, Russian Federation \\ ${ }^{2}$ Peter the Great St. Petersburg Polytechnic University, \\ 29, Polytechnicheskaya ul., St. Petersburg, 195251, Russian Federation,
}

For citation: Matveevskaya A.S., Pogodin S.N., Wang Jun Tao. Russia and China in the field of international tourism. Vestnik of Saint Petersburg University. Philosophy and Conflict Studies, 2020, vol. 36, issue 2, pp. 384-393. https://doi.org/10.21638/spbu17.2020.214

International tourism is an instrument of diplomatic, socio-cultural and economic cooperation of states that have realized the importance of international relation trend in the modern world. This is stipulated by the elevation of the role of tourism for the world economy and interstate diplomacy, for social and economic living conditions of the population, the formation of a state's identity in the international arena, for improving a country's reputation, and participation in foreign policy as a whole. The most dynamically developing region of the world economy is Northeast Asia, which has become a region with the greatest potential for development of the world tourism industry. Russia and China are superpowers in Northeast Asia and are rich in tourism resources and markets that will play an important role in the future global tourism industry. The purpose of this study is to provide comprehensive coverage of important events in the field of cooperation in tourism between China and Russia, to form a holistic picture of cooperation between the two countries in the tourism industry. The main method of research is analysis - aspects of the current international situation in the field of tourism are considered, and a detailed review of the situation of Russia and China as tourist destinations is conducted. The work was carried out on the basis of studying and using fundamental national and international research in the following scientific areas: mechanism of international cooperation between the two countries in international tourism, prescribed in treaties and agreements; Russian territories attractive to Chinese tourists; development of joint tourist routes. The results of the study showed that with regular contact between people from the two countries it is possible to create favorable conditions for cooperation and to achieve truly mutually beneficial results. Collaboration and cooperation of the states, national organizations on tourism development, makes it possible to increase the incomes of the states, attracting foreign capitals, and partially reorient the economy and legislation to attract foreign tourists. Successful diplomatic negotiations, and maintenance of a stable peaceful existence of

(C) Санкт-Петербургский государственный университет, 2020 
the world community, promotes the expansion of the tourism sphere that positively influences the economy and development of culture in the Russian Federation and the People's Republic of China.

Keywords: international tourism, cooperation between Russia and China, agreements and treaties on tourism, attractive tourist destinations in Russia, Russian-Chinese tourism forum, China Friendly program, international relations.

The data from the report of the World Travel \& Tourism Council states that the total contribution of tourism to the world's gross domestic product is estimated at $10.4 \%$, which is equal to $\$ 8.3$ trillion, with 1 out of 10 jobs in the world created in the tourism sector. According to the United Nations World Tourism Organization (UNWTO), a special UN agency for tourism, in recent years, the world trade of tourism services has been increasing in comparison with the trade of goods. According to the UNWTO, international tourism flows have doubled over the last twenty years from 0.68 billion inbound tourists in 2000 to 1.4 billion in 2018 and are estimated to reach 1.5 billion in 2019 . In the non-resource sector, tourism remains one of the largest items in international trade. According to the World Tourism Organization, tourism exports are ranked $3^{\text {rd }}$ in world exports after chemicals and mineral fuels including oil, overtaking the automotive industry [1]. Most developed countries consider international tourism to be a leading export item.

UNWTO forecasts “Tourism: prospects 2030" as well as statistical data of "UNWTO World Tourism Barometer" indicate high rates of international tourism development in the countries of Northeast and South Asia, ahead of the European Union and North America [1]. Since the early 1950s, tourism in China began to develop. The country's first international travel agency with branches in Beijing, Guangzhou, Shanghai, and other cities opened in 1954. Ten years later, the China National Tourism Administration was established in Beijing. 64.48 million tourists visited China by the end of 1998, of which 7.11 million were foreign tourists. At the beginning of 2000, there were 11552 tourism companies in China. Modern tour operators are capable of meeting the requirements of foreign tourists. China has set a goal to become the world's number one destination for inbound tourism by 2020 [2]. However, according to the UNWTO as of 2018, the leading countries in inbound tourism are France - 90 million tourists, Spain - 82 million tourists, and the USA - 73 million tourists. The People's Republic of China ranks 4th in the world by this indicator - 59.3 million tourists [1].

The most popular destinations for tourists from China for three years now remain: Thailand (about 8.8 million people), South Korea (about 8 million people), Japan (about 6 million), USA (about 3 million), Singapore (about 3 million), Vietnam (2.9 million), Malaysia (2 million), Indonesia (1.5 million), Russia (1.5 million), and Germany (1.4 million) [3].

China and Russia are friendly neighbors. As neighboring countries, Russia and China share a border of over 4300 kilometers, which initially created suitable conditions for exchange and cooperation in the tourism industry of the two countries. The first Chinese tourists in the USSR appeared in the early 1980s. It should be noted that the expansion of interstate relations between the USSR and China served as a basis for the development of business, and later mass tourism. September 24, 1988 was declared the official date when the tourist began, when there was an exchange of tourist groups between the two states. As a whole, 13 tourist groups totaling 1040 people visited the USSR that year. The Agree- 
ment "On visa-free group tourist trips of citizens" of May 26, 1993, which came into force, resulted in positive changes in the process of organizing tourist trips [4]. The growth in the number of Chinese visitors to our country was influenced by the "Agreement on visa-free group tourist trips" signed by the governments of the Russian Federation and the People's Republic of China in February of 2000. According to this Agreement, tourists from China and Russia can visit the countries without obtaining a visa as part of an organized group [5]. According to the Agreement, a group of citizens of one state consists of at least 5 and no more than 50 people who travel to the territory of another state for tourism purposes. The period of visa-free stay should not exceed 15 calendar days.

To date, we note a very effective mechanism of cooperation between Russia and China, which is reflected in various treaties, agreements, as well as activities and programs.

- "Agreement between the Government of the Russian Federation and the Government of the People's Republic of China on cooperation in tourism" (1993).

- "Agreement between the Government of the Russian Federation and the Government of the People's Republic of China on visa-free group tourist trips" (2000).

- The Russian-Chinese Agreement on Good Neighborliness, Friendship, and Cooperation (2001).

- Programs of cooperation between regions of the Far East and Eastern Siberia of the Russian Federation and North-East China (2009).

- Years of Russian and Chinese Culture (2006-2007).

- Years of Tourism (2012-2013).

- Years of Youth Exchange (2014-2015), both in the Russian Federation and the People's Republic of China [6].

- Memorandum of mutual understanding between the Federal Agency for Tourism and the operator of the Chinese national payment system UnionPay International. The adaptation of services for guests from China is actively developing in Russia. With the support and initiative of the Travel Association "World Without Borders", a large-scale program called China Friendly has been implemented since 2014. This major project, on the one hand, aims to create a comfortable environment for tourists from China, and on the other hand, aims to promote the tourist products of our country on the international market. The main goal of the project is to organize quality service for Chinese tourists in order to increase the flow of tourists from the People' Republic of China. Participants of the project include accommodation facilities, travel companies, show objects, restaurants and, shopping centers. Thus, to date, hotels, restaurants, museums and shops in 16 regions of the country have received the certificate of the China Friendly program.

- Memorandum of mutual understanding between the Federal Agency for Tourism (Russian Federation) and the China National Tourism Administration on further expanding cooperation in improving the quality of tourism services in Russia. As part of this document, a call center (+7-800-775-18-69, ext. 2) in Chinese is organized and the possibility of sending complaints and claims to hotline@ bezviza.com is provided [7].

Starting from 2014, the People's Republic of China has become a world leader in outbound tourism (over 110 million people from China travel abroad per year and annual 
expenditures of Chinese tourists exceed $\$ 170$ billion). The transition to a market economy has made it possible to form a Chinese middle class (shareholders, entrepreneurs, managers, etc.), who are able to pay significant amounts of money for education, culture, tourism, and entertainment. The economically active middle-aged population of 30-50 years old is the main consumer of tourist services. This amounts to approximately $30 \%$ of the country's total tourist flow. Travelers from China, who do not have long vacations, as well as for fear of losing their jobs, prefer to travel during public holidays (especially during "long holidays", such as the National Day of the People's Republic of China from October 1 to 7, Labor Day or May holidays from 1 to 5 May, Chinese New Year). Usually, tour durations are from 3 to 7 days [8].

According to the data for 2018, 4.2 million foreign tourists arrived in Russia, which is $10.5 \%$ higher than a year ago (3.8 million foreign arrivals in 2017). 1.26 million incoming Chinese tourists made the People's Republic of China the leader in terms of arrivals in Russia in 2018. A "budget tourist" comes to Russia from China, who reduces expeneses on everything, especially on the excursion program. However, Chinese tourists spend more than $25 \%$ of the tour's cost on souvenir purchases (they spend twice as much money as tourists from Europe, for example). Popular products are traditional Russian handcrafts, items made of amber, particularly souvenirs with the symbols of St. Petersburg and the USSR are actively purchased. Since 2008, the number of people belonging to the middle class has reached 75 million people. Forecasts for 2025 suggest that the number of such people will be more than 500 million. And that is why shopping tours are so popular among the Chinese population [9].

Siberian and Arctic tourist destinations are attractive as well. Tourists from China make up to $30 \%$ of group cruises to the North Sea, the North Pole, and the Russian Arctic National Park [10]. It is important to note that the People's Republic of China, as the country with the highest economic influence in Southeast Asia, is interested in polar research and the development of cruise destinations along the Northern Sea Route. Thus, the largest scientific research diesel icebreaker "Xue Long" ("Snow Dragon") has already made several voyages between Shanghai and Svalbard. The second icebreaker "Xue Long - 2", an even more powerful vessel for future escort of transport caravans along the Northern Sea Route, is currently under construction [11].

"In the summer season of 2017, the Russian Arctic National Park was visited by 1142 people from 36 countries, of which 209 were Chinese tourists, who became leaders among foreign tourists", - said the spokesperson for the Russian Arctic National Park, Yulia Petrova. Tourists from China choose tours on an icebreaker to the North Pole despite their high cost - from $\$ 28$ to $\$ 40$ thousand, depending on the level of comfort of the suite (duration of the trip is 11 days). The trips are operated by Poseidon Expeditions and Quark Expeditions. As a rule, every year at least one cruise on the icebreaker "50 Let Pobedy" is fully composed of Chinese tourists, approximately 120 people on board.

"Such cruises, consisting entirely of Chinese tourists, are fully adapted for them. On the icebreaker, all information is in Chinese, there is a Chinese menu, in the evenings guests sing Russian songs in karaoke. In 2016, 'Russian Arctic' published guidebooks in Chinese at the polar station of Tikhaya Bay, the most visited place in the archipelago of Franz Josef Land, which are distributed on 'Chinese' icebreaker cruises. But the collection of 'Russian Arctic' souvenirs in Chinese is not limited to this: it also includes pendants made of eco-material - felt, in the form of mittens, and insignia with the logo 
of the national park", - according to Yulia Petrova. Chinese tourists show an increased interest not only in the Arctic, but also in the Antarctic. According to the Chinese internet company Ctrip.com, China became the second largest tourist source in Antarctica in 2016-2017 [12].

Among other tourist destinations, the most interesting for Chinese tourists are St. Petersburg and Moscow. The influx of representatives from the PRC and the border areas of Transbaikal, Primorsky Krai, and Amur Oblast has increased. Shopping tours are especially popular there. The ruble exchange rate has fallen and therefore the Chinese consumer demand in our country has grown by almost $20 \%$ [13]. Tour programs connected with the centenary of the October Revolution turned out to be the most popular with tourists from the People's Republic of China. In 2017, the centenaries of the February BourgeoisDemocratic and the October Socialist Revolutions were celebrated. These events should be regarded as particularly significant for world history [14]. They certainly attracted the attention of would-be tourists from all over the world. Trips to Russia, determined by the interests of travelers in the history of revolutionary events, are usually classified as "red tourism". This term is used by workers in the tourism industry to refer to historical and cultural educational tourist programs based on the interest of foreigners to Russia as the first country of socialism. They use cultural resources from the revolutionary epoch, military themes, and socialist life. The "red" tourist theme is also popular with tourists from Japan and Korea.

The "Red Route" is a federal project that allows travelers to visit St. Petersburg (the city of the socialist revolution), Ulyanovsk (the birthplace of V.Lenin), Kazan (where the future "leader of the world proletariat" studied), as well as Moscow (where the outstanding figure of world history in the twentieth century worked, died, and is buried). The "Base route" (Moscow - Ulyanovsk - Kazan - St. Petersburg) lasts for 8 days and 7 nights. Among the existing routes in the summer season there is a trip with a three-day tour along the Volga River [15].

Within the framework of the international scientific and practical conferences devoted to the Eurasian studies, the participants often discus development of international tourism on the "Great Silk Road". To date, this route is one of the most famous and actively developing international tourism projects in Eurasia. Restoration of caravan trade routes, which stretched through the countries of Eurasia from II century B.C. to $15^{\text {th }}$ century, are the basis of modern tourist programs. Two main routes lie on the routes of the Silk Road. "Southern" - the first route went from northern China through Central Asia to the Middle East and Northern India. "Northern" - the second route ran from China to the Pamir Mountains, then in the Aral Sea region, from here to the Lower Volga and the Black Sea basin. In our opinion, the tourism programs under development as part of the Great Silk Road route are interesting for such countries as China, Uzbekistan, Tajikistan, Afghanistan, Kazakhstan, Turkey, and Italy. The program includes the organization of parking lots at places of worship as well as monuments and unique landscapes, the creation of a system of special tourist and ethnographic complexes, including new facilities for the production of yurts, nomadic mobile devices, decoration, and other household items. Developers aim to revive national cuisine, clothing, traditions and rituals, as well as organize schools and workshops of folk art, train personnel in this area of tourist services, horse breeding farms, etc. Such diverse tourist conditions and resources can be applied in the programs of such popular quests today, which can be in demand among both Russian and Chinese travelers. 
Russian tourist routes within the Silk Road are represented only by the North-Caspian region. However, proposals for new programs approved by the Import Substitution Committee have been presented in this region, for example, tourist programs with visits to Astrakhan, the villages of Evpraksino, Altynzhar, Kozlovo, Makovo, and others. Unfortunately, the authors acknowledge that such tourist programs are not so promising today.

The international tourist route - "The Great Tea Road", according to the authors, on the contrary, shows promising development in the future. Historically, the Great Tea Road, which connected Asia and Europe in the $16^{\text {th }}-19^{\text {th }}$ centuries, passed through China, Mongolia, and Russia. Many other goods were transported along the route, together with tea. The average length of the main land route from Moscow to Beijing was about 8.5 thousand versts (taking into account the progress on different sections). The road began in the Chinese city of Wuhan and was divided into many roads, trails, river routes - the routes passed through 150 cities, the main ones were Beijing, Urgu (Ulan-Bator), Maimachen (Altan-Bulag), Troitsko-Savsk (Kiakhta), Verkhneudinsk (Ulan-Ude), Slyudyanka, Irkutsk, Krasnoyarsk, Omsk, Tyumen, Yekaterinburg, Kungur, Irbit, Nizhny Novgorod, Kostroma, Yaroslavl, Moscow, and Saint Petersburg. The movement of trade caravans along water and land routes could take one year only in one direction. The tourist route "The Great Tea Road", 3 thousand kilometers long, offers travelers a variety of programs that have been implemented since 2017. The project is serviced by the "Star of Eurasia" train. The Trans-Siberian Railway is the main means of travel for the tourist route and travelers are offered to go by rail from China to the Ural Mountains. The main potential participants of the tour are tourists from the People's Republic of China. The information tour was organized in spring 2017. The route passed through the six largest Siberian and Ural cities (Chita, Ulan-Ude, Irkutsk, Krasnoyarsk, Novosibirsk, and Ekaterinburg).

The construction of the Eurasia high-speed railway is being carried out to develop transport links between the countries. In 2017, under the project "Eurasia" Beijing - Moscow, $3200 \mathrm{~km}$ were built in China from Beijing. According to the "Russian Railways" schedule, the construction of a highway for passenger traffic is to be completed in 2023. In 2026, the transportation of cargo is to begin. It is forecasted that by 2050, 20 million tons of cargo and almost 37 million passengers will be transported annually along the highway [16].

In an increasingly globalized world, states realize the importance of cooperation and collaboration in international tourism. Today, international forums and conferences [17] are held annually to discuss the importance of tourism and ways of developing the tourism sector. Travel with educational and business purposes is considered as one of the most important components of the modern tourist exchange. Business tourism is one of the most profitable types of tourism. Nowadays, travel with business purposes, be it international conferences or forums, exhibitions or fairs, is firmly established in many countries as the most rapidly developing economic sector, providing an influx of foreign currency and creating new jobs [18]. Business tourism is an essential tool to stimulate business activity, to boost industrial production and the expansion of services, to strengthen interregional and international cooperation, and to support a favorable image of the given area.

An important platform for interstate communication in tourism is the RussianChinese Tourism Forum, which has been held annually since 2012. In 2019, the Forum was held for the $7^{\text {th }}$ time. As usual, it discusses the prospects of mutual cooperation between the two countries in the field of humanitarian exchange and tourism. The Forum is annually attended by government agencies, public organizations, and representatives of 
the tourism industry, which repeatedly sign important agreements between specialized organizations of the partner countries. The Travel Association "World Without Borders" and the China National Tourism Administration organizes the Forum.

2018-2019 are declared the years of interregional cooperation between the Russian Federation and the People's Republic of China [19]. In June - July 2018, Russia hosted the FIFA World Cup. This event was also given special attention at the Russian-Chinese Forum 2018. The Travel Association "World Without Borders" together with Shankai Sports International signed an agreement to attract fans from China. The official Chinese distributor of tickets for the 2018 World Cup, Shankai Sports International, had the exclusive right to sell tickets to Chinese fans travelling to Russia. According to the agreement, the Chinese company recommended accommodation facilities, the service of which was prepared especially for Chinese tourists. And indeed, it should be noted that the flow of Chinese citizens with fan passports for the period of the Championship amounted to 67 thousand people, the second largest amount after Russian citizens (980 thousand people). Third place was taken by fans from the USA (52 thousand people) [20]. All the more interesting is the fact that football teams from neither China nor the USA were even able to pass the qualifying stage for the World Cup 2018. In 2022, China plans to hold the Winter Olympics, which opens wide opportunities for tourism development between our countries.

The Russian-Chinese Forum held in March 2019 was marked by experts with a new level of relations between the two countries. Forum participants emphasized the importance of the strategy of Russian-Chinese tourism development, dwelling not only on achievements, but also on perspective directions of mutual cooperation in this sphere. The program of business meetings within the framework of the Forum 2019 brought together leading tour operators, representatives of widely demanded museums, heads of global social networks and search engines in tourism, and Russian and Chinese bloggers.

In May 2018, the Concept of the Federal Target Program "Development of Domestic and Inbound Tourism in the Russian Federation (2019-2025)" (Order of the Government of the Russian Federation no. 872-r dated May 5, 2018) was approved [21]. According to it, by the end of 2025, the volume of tourist services provided to the population will amount to over 274 billion rubles, and the volume of services provided to the population by hotels and similar accommodation facilities will reach 373 billion rubles. It is expected that by the end of 2025 the number of organized tourists registered in electronic form through the state information system "Electronic Trip" in Russia will reach 6.78 million people per year. It should be noted that back in 2017, a visa-free regime for citizens of 18 countries, including China, was introduced in the port area of Vladivostok. Thanks to this, the Primorsky Krai was visited by 420 thousand people from China, and Vladivostok itself was ranked the third after Moscow and St. Petersburg by the number of tourists from China [22].

On February 6, 2019, at the forum of the All Russia Public Organization "Business Russia", the President instructed the Ministry of Foreign Affairs, together with Rostourism, to submit proposals to facilitate visa procedures for foreign tourists, including the issuance of electronic visas by March 31,2019. Today, a system of obtaining electronic visas for foreign tourists for a period of 3-8 days, on condition of purchasing a tourist package, is in development. According to experts, this will have a beneficial effect on increasing the tourist flow in our country. 
In particular, to promote the Russian tourist product, plans are underway to support activities and set up an international network of the national marketing center for tourism ("Visit Russia"). Within the framework of stimulating entrepreneurial and public initiatives, it is planned to provide subsidies to tour operators to compensate part of the costs within the agreement on the sale of tourist products in the sphere of domestic and inbound tourism, including those for the purpose of reducing the cost of tourist packages in the low season and for socially vulnerable categories of citizens.

International tourism, as a steadily growing part of the economy, implies closer cooperation between countries to solve interstate problems [23]. In his annual address to the Federal Assembly on February 20, 2019, the President of the Russian Federation said: "Our equal mutually beneficial relations with China today serve as an important stabilizing factor in global affairs, in ensuring security in Eurasia, and demonstrate an example of fruitful cooperation in the economy" [24]. The collaboration and cooperation of our states makes it possible to increase the income of the countries, attract foreign capital, and partially reorient the economy and legislation to attract foreign tourists and consistently develop the tourism sector. Successful diplomatic negotiations and the maintenance of stability of peace in the world community promote the expansion of the tourism sphere that positively influences the economy and cultural development of the states.

\section{References}

1. Official website of World Tourism Organization - UNWTO (2019). Available at: http://www2.unwto. org/ru/home (accessed: 03.11.2019).

2. Ducenko, S. V. (2013), The social space of Russian-Chinese tourism cooperation: status and prospects, Izvestiia Iugo-Zapadnogo gosudarstvennogo universiteta. Ser. Ekonomika, Sotsiologiia, Menedzhment, no. 2, pp. 145-156.

3. Yin Yong (2019), Study of the status quo of Sino-Russian cooperation in tourism and countermeasures, Jingji jishu xiezuo xinxi, no. 19, pp. 14-15. (In Chinese)

4. Junjing Jiang (2019), Chinese tourism in Russia: current status, Informatsionnyi vek, vol. 3, no. 3(8), pp. 41-50.

5. Zhao Lei (2017), Tourism development in Russia and China, Xueshu jiaoliu, no. 1, pp. 219-219. (In Chinese)

6. Sheng Haiyan (2018), Analysis of the state of Sino-Russian tourism cooperation, Xiandai jiaoji, p. 22. (In Chinese)

7. Bogolyubova, S. A. and Bogolyubov, V.S. (2018), Modern factors and problems of Russia's attractiveness as a tourist destination for Chinese tourists, Azimut nauchnykh issledovanii: ekonomika i upravlenie, vol. 7, no. 4 (25), pp. 48-52. (In Russian)

8. Guo Lijie (2019), Analysis of factors affecting the development of international tourism in Russia and China, Guangxi zhiliang jiandu daobao, no. 8, pp. 148-120. (In Chinese)

9. Wang Yunhe (2018), Current status and prospects of Sino-Russian tourism cooperation and development, Zhongwai jiaoliu, no. 46, p. 79. (In Chinese)

10. Ermolina, M. A., Kapustina, M. A., Matveevskaya, A.S. and Pogodina, V. L. (2019), Legal regulation of ecological tourism in Arctic, IOP conference Series: Earth and Environmental Science. 302, 012037. https:// doi.org/10.1088/1755-1315/302/1/012037.

11. Li, J. and Pogodin, S. (2019), "Made in China 2025": China experience in industry 4.0, IOP Conference Series: Materials Science and Engineering 497(1),012079. https://doi.org/10.1088/1757-899X/497/1/012079.

12. Official website of Touristic Association "World without borders" (2020). Available at: www.visit-russia.ru (accessed: 31.01.2020).

13. Zhao Xin (2019), Analysis of bottlenecks and problems of creating a cross-border tourism cooperation zone between China and Russia, Bianjiang jingji yu wenhua, no. 8, pp. 1-3. (In Chinese)

14. Pozdeeva, E. G., Trostinskaya, I. R., Evseeva, L. I. and Ivanova, R. A. (2018), Problems of personality type transformation in current conditions of Russian society, The European Proceedings of Social and Behavioural Sciences, vol. XXXV, pp. 1092-1099. https://doi.org/10.15405/epsbs.2018.02.128. 
15. Pogodina, V. and Matveevskaya, A. (2017), Geography of Tourism of the European Part of Russia, in Widawski, K. and Wyrzykowski, J. (eds.), The Geography of Tourism of Central and Eastern European Countries, Cham: Springer, pp. 375-435. https://doi.org/10.1007/978-3-319-42205-3.

16. Mulintseva, D. V. and Tretyakova, O. S. (2019), Study of modern Russian-Chinese relations in the field of tourism and prospects for their development, Nauka i turizm: strategii vzaimodeistviia, no. 10, pp. 41-45. (In Russian)

17. Kolomeyzev, I. V. and Shipunova, O.D. (2018), Sociotechnical system in communicative environment: management factors, International conference on research paradigms transformation in social sciences, vol. 35, pp. 1233-1241. https://doi.org/10.15405/epsbs.2018.02.145.

18. Evseeva, L. I., Bashkarev, A. A., Pozdeeva, E. G. and Tarakanova, T.S. (2018), Technologies of political system modernization in new communicative environments, The European Proceedings of Social and Behavioural Sciences, vol. XXXV, pp. 349-356. https://doi.org/10.15405/epsbs.2018.02.41.

19. Wu Shan, Wu Dan and Zhao Donglai (2019), Ichiyanjiang, China and Russia celebrate together, Heilongjiang huabao, no. 13, pp. 32-43. (In Chinese)

20. Official website of the Federal Agency for tourism (2019). Available at: https://www.russiatourism. $\mathrm{ru/}$ (accessed: 12.12.2019).

21. The Federal target program "Development internal and entrance tourism in Russian Federation (20192025)" (2020). Available at: https://www.russiatourism.ru (accessed: 05.01.2020).

22. Chen Qiujie (2019), Development of interaction between China and the Russian Federation in the field of tourism, Ekonomika i politika, no. 1 (13), pp. 44-48.

23. Zeleneva, I. V., Matveevskaya, A.S. and Ermolina, M. A. (2018), Dialogue of Civilizations - New Model of World Politics, The European Proceedings of Social and Behavioural Sciences, vol. XXXV, pp. 829836. https://doi.org/10.15405/epsbs.2018.02.98.

24. Official website of the Kremlin (2020). Available at: http://kremlin.ru (accessed: 23.01.2020).

Received: October 14, 2019

Accepted: March 19, 2020

Authors' information:

Anna S. Matveevskaya - PhD in Geographic Sciences, Senior Lecturer; annamatveevskaya@mail.ru Sergey N.Pogodin - Dr. Sci. in History, Professor; pogodin56@mail.ru

Wang Jun Tao _ PhD in Political Sciences, Assistant Professor; juntao2013@yandex.ru

\section{Россия и Китай в сфере международного туризма}

\section{А. С. Матвеевская ${ }^{1}$, С. Н. Погодине, Ван Цзюнь Тао}

${ }^{1}$ Санкт-Петербургский государственный университет,

Российская Федерация, 199034, Санкт-Петербург, Университетская наб., 7-9

${ }^{2}$ Санкт-Петербургский политехнический университет Петра Великого,

Российская Федерация, 195251, Санкт-Петербург, Политехническая ул., 29

Для цитирования: Matveevskaya A. S., Pogodin S. N., Wang Jun Tao. Russia and China in the field of international tourism // Вестник Санкт-Петербургского университета. Философия и конфликтология. 2020. Т. 36. Вып. 2. С. 384-393. https://doi.org/10.21638/spbu17.2020.214

Международный туризм выступает как инструмент дипломатического, социокультурного и экономического сотрудничества государств, осознавших значимость данного направления международных отношений в современном мире. Наиболее динамично развивающимся регионом мировой экономики является Северо-Восточная Азия, которая стала регионом с наибольшим потенциалом развития мировой индустрии туризма. Россия и Китай являются сверхдержавами в Северо-Восточной Азии, они богаты туристскими ресурсами и рынками туризма, которые будут играть важную роль 
в будущей индустрии глобального туризма. Целью данного исследования является комплексное освещение важных событий в сфере сотрудничества в области туризма Китая и России, формирование целостной картины взаимодействия двух стран в индустрии туризма. Основным методом исследования является анализ - рассмотрены аспекты современной международной ситуации в сфере туризма, также проведен детальный обзор положения России и Китая как туристских дестинаций. Работа выполнена на основе изучения и использования отечественных и зарубежных фундаментальных исследований по следующим научным направлениям: механизм международного сотрудничества двух стран в международном туризме, прописанный в договорах и соглашениях; привлекательные для китайских туристов российские территории; разработки совместных туристских маршрутов. Результаты исследования показали, что при регулярных контактах народов двух стран возможно создать благоприятные условия для сотрудничества и достижения действительно взаимовыигрышных результатов. Успешное проведение дипломатических переговоров, поддержание стабильности мирного существования мирового сообщества способствуют расширению туристской сферы, что положительно влияет на экономику и развитие культурной сферы Российской Федерации и Китайской Народной Республики.

Ключевые слова: международный туризм, сотрудничество России и Китая, соглашения и договоры по туризму, привлекательные туристские дестинации России, российскокитайский туристский форум, программа China Friendly, международные отношения.

Статья поступила в редакцию 14 октября 2019 г.; рекомендована в печать 19 марта 2020 г.

Контактная информация:

Матвеевская Анна Сергеевна - канд. геогр. наук, ст. преп.; annamatveevskaya@mail.ru Погодин Сергей Николаевич - д-р ист. наук, проф.; pogodin56@mail.ru

Ван Цзюнь Тао - канд. полит. наук, доц.; juntao2013@yandex.ru 